\title{
Inter-linkage between Hinterlands and Service Centers of Bima and Darbang VDCs in Myagdi District: A Rural Development Perspective
}

\author{
Beg Prasad Garbuja
}

\begin{abstract}
This study focuses on exploring the status and contribution of interlinkage relationship between service center and rural hinterland. The study was conducted in Bima and Darbang Village Development Committees (VDCs) of Myagdi district. This paper has used rural development perspective. The respondents were from 63 sample households including producers, consumers and service providers selected by using probability and non probability sampling methods. The primary data were collected through survey questionnaire, key informant interview, participant observation and focus group discussion whereas secondary data were generated from published and unpublished books, articles, journals, profile of VDCs and $D D C$. The study has revealed with various types of linkage between service center and rural hinterland i.e. service delivery, spatial or physical, administrative, economic, technological, financial and socio-cultural, educational and health service linkage. The study also highlighted productive role of remittance, international experience and adaptation of modern agriculture technology that has been positively affecting socio-economic life of the rural people. Further, joint efforts of public and private sectors' and local stakeholders' can be applied for developing and promoting service delivery opportunities and marketing facilities to the local people. The finding of the study has very strong implications to the local stakeholders for formulation of short run and long run local development plan in a similar situation.
\end{abstract}




\section{8| Beg Prasad Garbuja}

Keywords: Rural development, inter-linkage, urban service center and rural hinterland

\section{Introduction}

Rural development in general means development of agriculture based activities and village industries that can uplift the socioeconomic situation of the small farmers, tenants, landless and other disadvantage groups (Chaudhary \& Pasa, 2015). But in particular, rural development without inter-linkage between rural hinterland and urban service center cannot be imagined. Rural hinterland are small centers that provides goods and services to the rural people and also relay on urban areas or bigger service centers to supply primary and secondary goods and services (Friedman,1975). It is a road, that keeps inter linkage relationship between service center and rural hinterland just for trade activities and service delivery however physical location, population density, and available resources are considered as influencing factors ([ICIMOD], 1998).

More specifically, the term inter-linkage denotes the functional relationships between market center and rural hinterland to provide various types of service delivery opportunities to the beneficiaries (Pradhan, 2004). The natures of market centers are consist of two types such as mobile and fixed. Mobile market centers are not remained as viable institutions at a fixed location, but traders and consumer meet periodically in predetermined places with selling and purchasing purposes whereas fixed market centers permanently formed where the range of a good and service is larger than the threshold or when demand is sufficient to support permanent trade based activities (Pradhan, 2004).

In practice however Nepalese rural people have been involving in both types of market system but still majorities of them are living with poor service delivery facilities and unproductive interlinkage with market centers and rural hinterlands. Reasoning that they are applying traditional knowledge, technologies and skills for livelihood struggle and living with poor subsistence farming or low production. For addressing such a problem productive and transformative inter-linkage relationship between service centers and rural hinterlands throughout the country is compulsion which 


\section{9| Beg Prasad Garbuja}

cannot be possible without visionary rural development plan and policies. Thus, this symbolic study tried to examine status and contribution of inter-linkage relationship between service center and rural hinterland especially in Bima and Darbang VDCs of Myagdi district. The objective of the study is to analyze the status of urban rural linkage practices and its contribution in socio-economic life of the rural people in Bima and Darbang VDCs.

\section{Methodology}

I have selected Bima and Darbang VDCs as a field of study. By assessing the relationship between Bima and Darbang VDCs this would help to understand the prospects and challenges in interlinkage relationship between rural hinterlands and service centers. Both primary and secondary data were collected to generate information. More specifically, in a regular day approximately total 100 producers/consumers (approximately 90 households' members from Bima and 10 from Darbang) exchange their service and goods in service center Darbang. Similarly, total 232 service providers (194 in Darbang and 38 in Bima) or local shopkeepers are providing various service delivery opportunities to the producers and consumers. Out of total 100 producers/consumers, 33 sample respondents (male and female) were randomly selected which is 33 percent sample population. And out of total 232 service providers, 30 sample respondents (male and female) were purposively selected that is 13 percent sample population. Households' survey, focus group discussion (FGD) and key informant interview was applied as techniques of data collection in which survey questionnaires, FGD guidelines and interview checklist were applied as major tools. I have considered how the research purposes, contents, methods, reporting and outcomes abide by ethical principles and practices (Cohen et al., 2007, p.70).

\section{Study Area}

Bima a recently grown hinterland of the VDC is situated above 1200 meter from the sea level. It lies within $43.04^{\circ}$ to $93.53^{\circ}$ easting and $29.20^{\circ}$ to $29.47^{\circ}$ northing with 1,607 hector total area (VDC Profile 2014). There are 419 households with 1,856 total population where male population is 842 and female 1,014 (CBS, 2012). It has 


\section{0| Beg Prasad Garbuja}

cold wet climate and alluvial soil. The river side is full of sand and other land is covered by slope area and stone hills. Agriculture and remittance is a primary occupation of the local people. Purchasing capacity of the people is increasing day by day because of remittance and commercial farming activities reasoning that demand of goods and services are mounting day by day. The hinterland is stretched from north to south along with 9 kilometer Darbang road under administrative unit ward no. 2 and 3 and it has a direct road linkage with national highway.

Darbang bazaar is marketing center of Bima. Darbang and it has several other smaller hinterlands to provide good and service delivery facilities. The VDC is situated within $28^{\circ} 23^{\prime} 00^{\prime \prime}$ to $28^{\circ}$ $26^{\prime} 28^{\prime \prime}$ North and $83^{\circ} 22^{\prime}$ '29" to $83^{\circ} 22^{\prime}$ '30" East. It is located at the height of 10,394 feet covering total area 1891 hector land and regarded as a gateway point of northern high hill area covered by forest. Darbang is a very old market center for its surrounding settlements and there are 904 households with total 3,595 (1,645 male and 1,950 female) population (VDC Profile, 2014). It was a residential area since long before. Local people from Bima and other hinterlands travel to Darbang bazaar in order to purchase primary and secondary products and in order to get various services delivery opportunities however it is also connected with Beni, Baglung and Pokhara i.e. the higher market centers of western region.

Farming activities and remittance are primary occupation of the majorities of the rural people in these. In fact, agriculture sector has been contributing a third of the total national Gross Domestic Product (GDP) and thus it is regarded as one of prioritized sectors for the economic development of the country (agriculture development strategy [ADS], 2012). Agro based production-distribution and service delivery networking is major function of urban rural linkage. However, here in study area the urban rural linkage activities are found to be moderate satisfactory. Darbang has only one gravel road network connected with Bima village as year around road service. The means of transportation are limited numbers of Jeep, mini-truck, pick-up van, motorcycles, taxi, tractor, horse, mules and porters. Only 10 hours a day transportation services are available to the local people. Thus, it is not sufficient to average 100 travelling consumer each day. It is very necessary to develop road condition and increase 


\section{1| Beg Prasad Garbuja}

the number of means of transportation. During field survey, it was found that out of total 33 sample consumers 39.39 percent used porter, 24.24 percent used mules, 21.21 percent used motorcycle and least 15.15 percent consumers used Jeep as the means of transportation to carry goods and services.

Local people are supplying their agro based production i.e. food, meat, fruits, dairy products and herbal medicines in service centers especially in Darbang, Beni, Baglung and Pokhara. One of key informant argued that educational status of the farmers, availability of modern technology, marketing and irrigation facilities equally have been affected farming and marketing system in these areas. But Darbang bazaar is somehow helping to supply some modern technology, chemical fertilizer and pesticides/insecticide. Further must need to establish cold storage, seed bank and food processing centers for productive agriculture based activities and transformative inter-linkage relationship between service centers and rural hinterlands. The table one and two tried to reflect upon occupational and educational status of the participants (producers and consumers) and various types of service delivery units run by local people that can unpack glimpse of inter-linkage relationship between service centers and rural hinterlands in these particular VDCs

\section{Table 1: Occupational/Educational Status of Sample Producers and Consumers}

\begin{tabular}{|c|c|c|c|c|c|}
\hline Occupations & $\begin{array}{l}\text { Respon- } \\
\text { dents }\end{array}$ & Percent & Education & $\begin{array}{l}\text { Respon- } \\
\text { dents }\end{array}$ & Percent \\
\hline Agriculture & 11 & 33.33 & Illiterate & 7 & 21.21 \\
\hline Remittance & 4 & 12.12 & Non formal & 5 & 15.15 \\
\hline $\begin{array}{l}\text { Local busi- } \\
\text { ness }\end{array}$ & 6 & 18.18 & Primary & 8 & 24.24 \\
\hline Wage labor & 4 & 12.12 & $\begin{array}{l}\text { Lower sec- } \\
\text { ondary }\end{array}$ & 4 & 12.12 \\
\hline $\begin{array}{l}\text { Private/Govt. } \\
\text { Job }\end{array}$ & 3 & 9.09 & Secondary & 6 & 18.18 \\
\hline Entrepreneur & 5 & 15.15 & $\begin{array}{l}\text { Higher sec- } \\
\text { ondary }\end{array}$ & 3 & 9.09 \\
\hline Total & 33 & 100 & & 33 & 100 \\
\hline
\end{tabular}


The table (1) highlights the information on occupational and educational status of the sample respondents (local producers and consumers). From the data fact it is found that most (33.33\%) of the sample respondent followed agriculture as a primary occupation and least $(9.09 \%)$ followed private or government job whereas in case of educational status, most (24.24\% sample respondents passed primary level and least (9.09\%) passed higher secondary level education life. The data indicates that agriculture and remittance are major source of earning of the local people and farming activities are followed by both literate and illiterate farmers, agriculture graduates and those youths who have international experience on farming activities. Therefore, an attention must be paid to increase their knowledge and skills on commercial farming and food processing.

\begin{tabular}{cllll}
\multicolumn{4}{c}{ Table 2: } & Service Delivery Units in Bima and Darbang VDCs \\
SN & Functional Units & Bima & Darbang & Total \\
1 & Rural industry & 5 & 17 & 22 \\
2 & Trading & 0 & 4 & 4 \\
3 & Wholesale shop & 2 & 17 & 19 \\
4 & Retail shop & 16 & 102 & 118 \\
5 & Health center & 1 & 6 & 7 \\
6 & Educational center & 5 & 8 & 13 \\
7 & Information service & 1 & 3 & 4 \\
8 & Financial service & 3 & 6 & 12 \\
9 & Professional service & 1 & 11 & 9 \\
10 & Govt. administrative center & 2 & 7 & 2 \\
11 & Catering service & 0 & 2 & 10 \\
12 & Personal service & 2 & 8 & 3 \\
13 & Entertainment center & & 3 & $\mathbf{2 3 2}$ \\
14 & Others & 0 & 0 & \\
Total & & $\mathbf{3 8}$ & $\mathbf{1 9 4}$ &
\end{tabular}

Source: Field Survey, 2015

The table (2) illustrates on information about total service delivery units in these center and hinterland. From the data fact it is found that there are total 232 service delivery firms with 12 functional units in Darbang and 38 service delivery firms with 10 functional units in Bima. Local shop found to be dominant service delivery unit in both areas in which there are sixteen retailing and two wholesale shops in Bima and 102 retailing and seventeen wholesale shops in Darbang bazaar. Darbang bazaar is located at strategic location, where 17 industries, 4 trading, 17 wholesale shops, 102 retail shops and 8 personal services are established. Now Darbang is grown as service center for many hinterlands of Bima and Darbang VDCs. 


\section{3| Beg Prasad Garbuja}

Field observation and focus group discussion with entrepreneurs at Bima show Darbang is drawing maximum goods and service from Bima than providing secondary production to the surrounding people. This activity is creating both backward and forward linkage with Darbang.

\section{Rural development}

Rural development is a highly prioritized strategy of sustainable local development because of excessive exploitation of natural resources due to urbanization and industrialization (Rural urban partnership program [RUPP], 2003). Function of market center play vital role in local development activities especially through reciprocal relationship between urban centers and rural hinterlands. It has been realized that to establish inter-linkage between rural area and hinterland, various factors play vital role. Globally, there is growing interest to study inter-linkage relationship between urban service center and rural hinterland by development planners in recent years. In the reference of various types of inter-linkage, there are basically nine types of linkage between rural hinterland and urban center. They are physical, economic, socio-cultural, service delivery, technological, population movement, political, administrative and organizational (Rondenelli, 1980). The central place theory offers goods and services for consumption to the population of central place itself. The population of tributary areas within the range of goods and services being offered by the center. According to the theory, development occurs in the center first and gradually expands to the surrounding areas. The concept explains the spatial pattern of the relationship between market centers and hinterland activities on the basis of factors such as threshold and range (Christalleer, 1966). Similarly Friedman (1973) developed four stage of linkage; rudimentary, inception, industrialization, industrial maturity and mass consumption in core-periphery model.

Similarly, Von Thunen (1826) has recognized land use model or influence of economic factor of the spatial organization of agriculture. His model assumed that the agricultural intensity decreases as the distance increases from the center. Burghardt (1971) studied gateway model to explain about gateway settlement initially develops in response to trade or to the setup of sparsely populated frontier areas, 


\section{4| Beg Prasad Garbuja}

and therefore are located in sits or considerable transport.

Misserchmidt (1980) has studied inter linkage relationship between gateway and hinterland at Marsyangdi River Valley, Nepal. He argued that gateway communities develop either as a response to increased trade to the settling to sparsely populated frontier areas. Those communities located along natural corridor of craft productivity; dense population, high demand or supply of scare resources; and, at the interface at different technologies or levels of socio-political complexity. Sharma (1998) has also studied the development trend and pattern of small towns in Hindu-Kush Himalayan region. He focused on urbanization process in the mountains and strategic issues for the promotion and development of market towns in the Himalayas.

Likewise, Pradhan (1997) has studies the market center and hinterland relations and found that potential markets could act as development or service delivery networking for rural hinterlands especially for agricultural development activities. Guragai (1999) has studied the in-migration pattern the newly developed small towns from the surround villages and impact in the market center development. He studied the rapidly growing market, Basantapur in Terathum district, located at the Dharan-Mayanglung road. Where the road-link has become strong pull factor for in-migration at Basantapur and has led to the attraction of people from adjoining rural village. RUPP has also conceptualized urban based local development through rural-urban linkages basically for trade and service related interactions between urban centers and rural hinterlands. The program premises are devised based on the problems experienced in the past development efforts and to address them in a holistic manner (RUPP, 2003).

Reflecting upon inter linkage relationship between urban and rural areas; the regional development policy was introduced in Nepal in 1974. Accordingly, government of Nepal implemented regional development concept in the central level and established at least nine to seventeen service centers in each district to provide basic rural services. The service center strategy is aimed at integrating urban centers and rural hinterlands, building the capacity of small 
Figure 1: RUPP Strategy fer Rural Urban Linkage

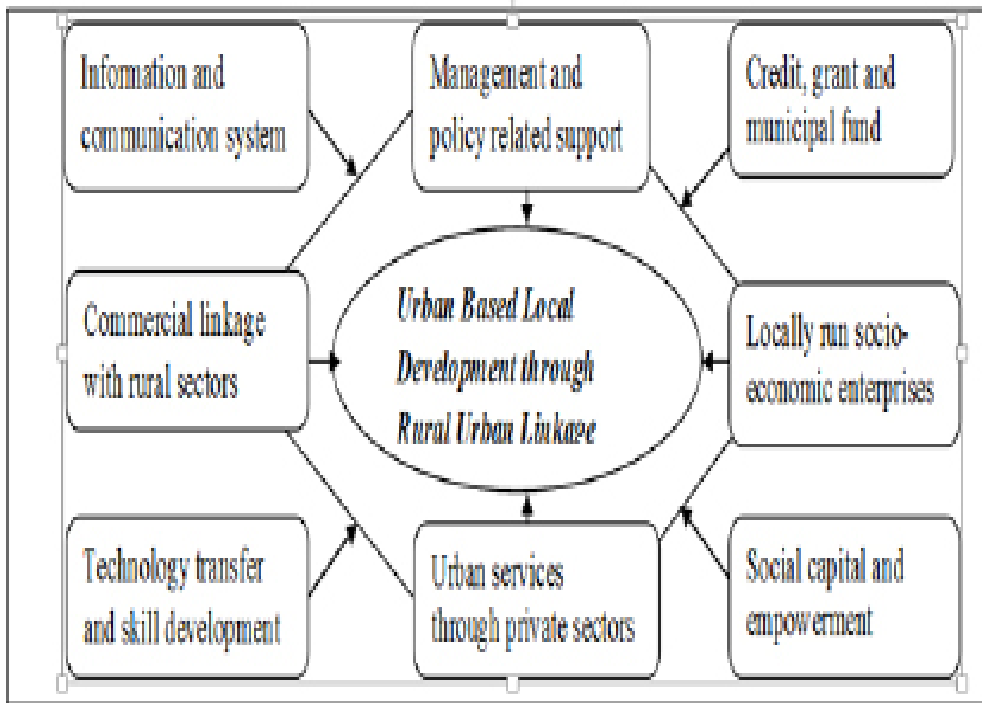

\section{l. Source: RUPP, 2003}

achieved the expected goal to assess the magnitude of potential of existing market because the inter linkage dimension between urban centers and rural hinterlands areas have not been considered. Later eighth plan (1993-1998) aimed to improve the relationship between cities and villages by developing small market towns and market centers for promoting rural development activities

\section{Discussions and Findings}

The field data are presented and analyzed under case study methodology. The subjective and objective data interpretation of participants' upon accessibility of marketing facilities, distribution pattern of local production and urban rural hierarchical linkage system practiced by local people affect in rural development activities were considered. Along with that some brief information about the study areas are also highlighted.

\subsection{Service Delivery Linkage}

Status of inter-linkage relationships for service delivery opportunities found moderately satisfactory in Bima and Darbang 


\section{6| Beg Prasad Garbuja}

VDCs. However, status of gravel road networking, alternative means of transportations, population distribution, availability of various service delivery functional units and commercial production are some of potential factors to increase service delivery linkage between service center and rural hinterlands. The equation makes clearer about present status of service delivery linkage in these areas.

We have, $d p=X i / P$ where $X=10,000$ population

$[\mathrm{d} p=$ density of population, $\mathrm{xi}=$ number of similar service, $\mathrm{P}=$ population receiving service, 10,000population- receive service per 10,000population.

Hence, $\mathrm{dp}=1 /(75400+2465) \mathrm{X} 10,000$ Population $\mathrm{dp}=\mathrm{x}$ Population $\therefore \mathrm{dp}=1.0054$ Population shows service delivery ratio i.e. 1.0054 per 10,000 populations and poor inter-linkage relationship between Bima and Darbang.

\subsection{Administrative Linkage}

Bima and Darbang VDCs lie in Myagdi district. However, Darbang is newer settlement then Bima but access of direct road linkage with district headquarters and safety base police station and subadministrative office is located in Darbang. Local security activities are managing by Darbang police station and sub- local development office. People from Bima travel to Darbang for their administrative and documentation works. This creates a strong administrative linkage between Bima and Darbang. Given equation make clearer about administrative service delivery linkage.

We have, $\mathrm{dA}=\mathrm{Xi} / \mathrm{P}$ X $100 \mathrm{M}^{2}$

Here $\mathrm{dA}=$ Density of area, $\mathrm{x}=$ number of similar type of service, $\mathrm{P}=$ Population

Hence, $\mathrm{dA}=7 / 3672 \mathrm{X} 10,000 \mathrm{~m}^{2}$

$\therefore \mathrm{dA}=0.19 \mathrm{M}^{2}$ shows not satisfactory status of administrative linkage as well.

\subsection{Physical Linkage}

Darbang is a service center of Bima. It is closely connected to each other. Darbang lays Southern border of Bima VDC. In regard of natural resource utilization, Bima is in upstream and Darbang 


\section{7| Beg Prasad Garbuja}

is in downstream. Same river serves both places. This both place are linked by a gravel road. For assessing physical or spatial linkage between Bima and Darbang bazaar I have also applied breaking point theory:

Formula is $\mathrm{d} j \mathrm{x}=\frac{\mathrm{d} j \mathrm{f}}{1+\sqrt{\frac{\sqrt{a}}{\sqrt{a}}}}$

[Here: djx- braking point of two location $\mathrm{i}=$ location $1, \mathrm{~J}$ location 2, d= distance of two location, $\mathrm{P}=$ Population]

We have,

Population of Darbang $=3595$, population of Bima $=1856$ and distance between Bima and Darbang $=9 \mathrm{~km}$

Hence dix $=9 / 1+\sqrt{3} 3595 / 1856=3,07 \mathrm{~km}$ (breaking point)

\section{Figure 2: Breaking Point between Bima and Darbang}

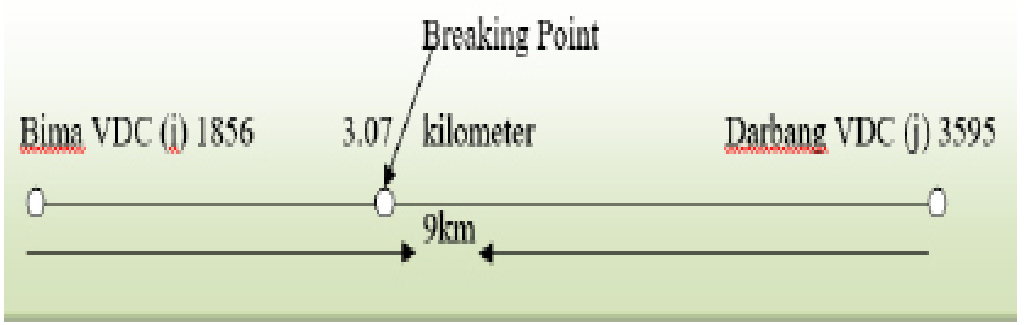

\subsection{Economic Linkage}

Economic inter-linkage relationship between service centers and hinterlands can be regarded as one of the prominent function of rural development. Economics status of the producers, consumers and service providers positively affect marketing function in any particular areas. During focus group discussion among producers, consumers and service providers it is found that Bima and Darbang bazaar are closely interlinked with economic activities. Majorities of the local people of Bima and Darbang VDCs are producing seasonal and off seasonal vegetables, aalinchi, lentil, ginger, amriso broom, bamboo product (Doko, Dalo, ghum, Thunse, Nanglo), dairy products, seasonal fruits, natural herbal medicines and 


\section{8| Beg Prasad Garbuja}

rearing livestock for agriculture and commercial purpose. And such productions are supplying in service centers especially in Darbang, Beni, Baglung and Pokhara through producers himself and layers of mediators. The information below makes clearer about economic status of the total sample respondents (producers/consumers and service providers).

\section{Table 3: Annual Income Status of the Respondents}

\begin{tabular}{|l|ccc|}
$\begin{array}{l}\text { Monthly Income } \\
\text { In NRs }\end{array}$ & $\begin{array}{l}\text { Monthly } \\
\text { Expenditure } \\
\text { In NRs }\end{array}$ & $\begin{array}{l}\text { Sample } \\
\text { HHs }\end{array}$ & Percent \\
\hline$<20,000$ & $<10,000$ & 9 & 14.28 \\
\hline $20,000-29,000$ & $10,000-20,000$ & 11 & 17.46 \\
\hline $30,000-49,000$ & $20,000-30,000$ & 17 & 26.98 \\
\hline $50,000>$ & $30,000>$ & 26 & 41.26 \\
\hline Total & & $\mathbf{6 3}$ & $\mathbf{1 0 0}$ \\
\hline
\end{tabular}

\section{Source: Field Survey, 2015}

The table (3) depicts the information on monthly income and expenditure status of the households of sample respondents (producers, consumers and service providers). From the information it is found that most 41.26 percent households earn more than 50,000 NRs and expense more than 30,000 NRS monthly and least 14.28 percent households earn less than 20,000 NRs and expense less than 10,000 NRs monthly. Similarly, 26.98 percent households earned 30,000-49,000 NRs and expended 20,000-30,000 NRs whereas 17.46 percent households earned 20,000-29,000 NRs and expended 10,000-20,000 NRs monthly. The data indicates that economic status of the local people is found to be satisfactory however the level of income can be increased through commercial farming and good networking of service delivery facilities. During focus group discussion, Mr. Man Bahadur Magar (name changed) expressed that because of traditional farming system local people are earning low level of income however some of farmers who are practicing commercial farming have been increasing their level of income and farming knowledge since more than seven years. Further he also stated that the low level of income can be transformed especially from commercial farming activities and marketing facilities to the end government mechanism have to establish cold storage and food processing facilities and also have to provide knowledge and skill 


\section{9| Beg Prasad Garbuja}

development training to the local people.

\subsection{Technological Linkage}

Technology is generally means the well combination of energy, tools and knowledge for making, using and doing useful thing that has been identified as one of the important factors that bring socio-economic change (Merill, 1968). Similarly, technology adaption is defined as a decision to make use of new idea as the best course of action that passes through five different steps (Rogers \& Shoemakers, 1971).

Awareness stages- The individuals learn of the new ideas but lakes of information.

Interest stage- The individuals develops interest in the individual develops interest in the innovation and seeks additional information about it.

Evaluation stage- The individual mentally applies the new idea to his present, anticipate future situation, and decides whether not to try it.

Trial stage- The individual actually applies the new idea, knowledge or tool in a small scale to determine its effect in output production in his or her situation.

Adoption stage- The individual uses the idea continuous on full scale.

Reflecting upon the ideas of Keeping Merill, Rogers and Shoemakers what I came to realize that adaptation of modern technology is inevitable for commercial farming activities in these areas. No doubt, rural economy of the country is still dominated by agriculture sector therefore attention have to pay for productive technological linkage between service centers and rural hinterlands so that farmers can get modern knowledge, skill and technologies in cheap and best prices in any time. In practice, still most of the farmers are using traditional knowledge and technology in production practice but slowly it is replacing by modern mechanical tools like; tractor, thrasher machine, water pump, diesel/petrol generator, new farming knowledge and skills as well as advance appropriate hand- 
use tools like; chemical sprayer because of technological linkage between Bima and Darbang bazaar. Along with that there are several alternative technologies that help to increase livelihood of people viz. solar panel, sola dryer, solar cooker, improve cooking stoves, briquette, biogas, advance farming technology etc available in service center however local people are using them minimally.

\subsection{Financial Linkage}

Financial activities are main factor to develop any particular areas as a hinterland, service center, growth center, market center, urban center and city center. Such activities in these area are regulating by various financial institutions such as; Nepal Bank, Gramin Bikash Bank, Rastraya Banijya Bank, Agricultural Development Bank, Private Banks, Cooperatives and money lenders. These financial institutions are providing loan or credit support service facilities to the local producers and businessman to accelerate agriculture production, rural industries and business activities to the local people. All these financial institutions are serving to local people from Darbang bazaar except two cooperatives and some money lenders are also performing financial support to local people in Bima. Therefore, financial linkage activities are found to be satisfactory however to make this relationship more profitability local people have to invest credit capital in productive sectors especially in commercial farming activities and rural based industries sectors. During field survey it is found that out of total 63 sample respondents, majorities 88 percent of them are getting financial services from government and private bank whereas only 12 percent of them are getting required credit capital from local money lenders.

\subsection{Socio-cultural Linkage}

Geographical structure of Bima and Darbang VDCs determine the varied cultural diversity that has been preserving and conserving by local people. Especially, local song, folk-lore, folk-ways, cultural dances, religious practices, fair and festivals, housing pattern, art, craft, and archaeological monuments like temples, pauwa, pati, satal, and natural water tape have been conserve since generation to generation. In fact, cultural heritage in these VDCs have been conserving through diversified cultural groups. Bima and Darbang 


\section{1| Beg Prasad Garbuja}

both place have similar socio-cultural feature. The Magar, Kami, Damai, Bramhan, Chhetri, Thakali, Gurung and Chhantyal are major the ethnic groups in this area. Number of Magar can be seen majority as compare to others groups where number of Gurung and Chhantyal, are significantly low. Among them, some the Magars, Thakalis, Gurungs and Chhantyals speak their mother language, others speak in Nepali.

Most of the ethnic groups are following Hindu and Buddhist religion but some of them are also following Christian religion too because of modernization and acculturation. Hindus celebrate Vijaya Dashami, Tihar, Janai Purnim, Sharoswati Puja etc festivals. Buddhist celebrates Lohsar, Buddha Jayanti, Maghe Shakarenti, Bhumi Puja, etc festival. All of the religion has own traditional birth, marriage, death custom. Reasoning that most of them used to celebrate various rituals and rites conditionally such as; birth rituals, marriage ceremony, marriage anniversary and funerals etc. It is a special identity of the people as well as culture of the ethnic group. Though, such cultural identity is also based upon their economic status. By the way, the most common dress and ornaments that are used in majestic dress pattern. In this stance, Thakali culture signifier richness in different dress. The women wears Gawan (Phariya), Makhamali Choli and itemed ornaments in vary part of their body; especially in ear, nose, neck, forehead, hand, foot and in fingers etc. Similarly, gentle man wears Nepali dress up like; daura, suruwal, kot, Bhadgaunle topi (black cap). Socio-cultural relationship among local people found more supportive and cooperative in these areas because of frequent meeting among local members, relatives, neighboring members in cultural functions. During key informant interview a participant shared that inter caste marriage system is common in these area which is in fact positive aspect for sociocultural development

\subsection{Educational and Health Linkage}

Education is one of the most important activities that enable humans to achieve their fullest personal, spiritual, mental, social, and physical potentials. Therefore, education means the acquisition of knowledge, understanding, intelligence, conscience, wisdom and so forth (Rana, 2007). Philosophically education makes human being 


\section{2| Beg Prasad Garbuja}

disciplined, critical for practical reasoning, rational and emancipation of civilization (Kant, 1993). Here in rural Nepal students are getting educational opportunities from public and private schooling system. In present there are total 7,797,472 students in which 85 percent are in 34361 public (community) schools and 15 percent are in 11000 private (Institutional) schools (MOE, 2012). In study area there are total 13 educational institutions ( 8 in Darbang and 5 in Bima) and six training institutes.

During field survey it is found that majorities of the of the local students are continuing their education life in community school however some of them are studying higher education even in different cities like Baglung, Beni, Pokhara, Kathmandu and foreign countries. Similarly, there are only seven health service centers in these areas where most of the local people get medical facilities from sub health post. However, some patient of chronic diseases also visit district, regional, national and international hospitals. During focus group discussion participants shared that status of health service facilities in these VDCs are more critical as compare to urban areas. Though it is not a case of we people whole rural people are suffering from such burning problems. Further, one sub- health clinic is established in 1997 at Bima which is located at lower settlement of Bima VDC. Patient from Bima and surrounding reach this service sector in order to get health services where most of the services like X-ray, VideoX-ray, and Pregnancy services are available. Health service unit and working efficiency of the health worker need to increase to provide better service to the local people.

\section{Conclusion}

Government has been implemented various plan, policies and program in order to strengthen rural development activities. It is rural development activities that provide road and transportation, irrigation and health facilities, financial and marketing and in/formal educational opportunities and skill development trainings to the rural people. Transformative inter-linkage relationships among urban service centers and rural hinterlands can provide good networking of service delivery that foster local production and contribute to sustain rural livelihood. Thereby, from the perspective of rural development, inter-linkage relationship among service centers 


\section{3| Beg Prasad Garbuja}

and rural hinterlands can bring drastic change in socio-economic life of the rural people through various kinds of inter-linkage such as; service delivery, spatial, administrative, economic, financial, technological, socio-cultural, and educational and health.

Reflecting upon rural development perspective, I have come up with my conclusion that status and contribution of inter-linkage relationship between service center and rural hinterlands in the study area seems satisfactory however it is not more than enough. The economic and educational status of the respondents found sound good. They are investing their income in productive sectors and also investing in quality education of the children. Local student have good accessibility of higher studies even in national and international cities. However, still condition of road networking, transportation facilities, and adaption of modern technology found to be unsatisfactory. But status of agriculture production and distribution and agro based rural industries seems moderately sound because of commercial farming and culture of investing in productive sectors. However, the trend of foreign employment is increasing and active population working in farm activities are migrating day by day but most of the youths have been working in developed countries with very good salary. Up to this point, remittance in these areas has been playing key role for collecting, allocating and mobilizing financial resources. Might be in future migrated youth will come up with fruitful experiences and benefits to others.

Even some of agriculture graduates and active youth who have international experience on farming are also engaging in commercial farming activities. Essential service delivery functional units are providing their inter-linkage services to the local people who come from their catchment areas. Therefore, the living standards and quality of life of the local people can be increased through commercial farming system which is impossible without increasing demand of modern technologies, modern inputs and supplying irrigation facilities and sufficient alternative energy. Because of modernization and globalization effect local farmers are slightly replacing traditional knowledge and technology related to farming and utilizing natural resources practice. Local people are also changing their perceptions that they are also one of the stakeholders for supporting rural development activities and thus involving in 
commercial farming and various trade based activities. Finally, there is a reciprocal inter-linkage relationship among service centers (Darbang, Beni and Pokhara Bazaar) and various rural hinterlands of Bima and Darbang VDCs and surrounding areas that has been forming rural economy in general and fulfilling the basic need, self esteem and freedom of the local people in particular.

\section{References}

ADS (2012). Preparation of the Agriculture Development Strategy (ADS)-Assessment Report.

Burghartd, A. F. (1971). A Hypothesis about Gateway Cites. Annals of the Association of American Geographers, Volume 61.

Central Bureau of Statistics (2012). Census Report 2011. Author.

Chaudhary, P. K. \& Pasa, R. B. (2015). Agriculture education for rural development in Nepal. Journal of Training and Development, Vol. 1 (1), 38-45. Author.

Cohen, L., Manion, L., \& Morrison, K. (2007).Research method in education (6th ed.) London: Taylor \& Francis Group.

Csristaller, W. (1966). Central Place in Southern Germany. N.J.: Englewood Cliffs.

Friedman, J. (1975). The spatial organization of power in the development of urban systems. In: J. Friedman and $W$. Alonso (eds.), Regional Policy: Cambridge (Mass): MIT Press.

Guragai, R. K. (1999). In-migration and Spatial Expansion of Basantapur Market Center [Unpublished Master Thesis submitted to Tribhuvan University].

ICIMOD (1998). Integrated Rural Development in Nepal-A review: International center for integrated mountain development (ICIMOD) . ICIMOD occasional paper 2, Kathmandu.

Kant, I. (1993). The quarterly review of comparative education. UNESCO: International Bureau of Educational Association for Bilingual Education 8 (2), 15-3.

Merill, R. S. (1968). The Study of Technology in the Encyclopedia of Social Science (Ed.) D.C. Sells. New York: Macmillan.

Ministry of Education (2012). Department of Education, Flash Report, 2011. Author.

Misserchmidt, D. A.(1980), Gaetway hinter relation in changing Nepal. CNAS Journal, Volume 8 (1). Author. 
National Planning Commission (1993). Eight Five Year Plan (19931998). Author.

Pradhan, P. K.(1997). Market Center and Hinterland Relation in Lalitpur District, Nepal. Klagenfurter Geographische Shcriften, Heft 17, Institut fur Geographie und Regionalforshung der Universitaet Klagenfurt, Austria.

Rana, S.P. (2007). Foundation of education. Kathmandu: Vidyarthi Publications.

Rogers, E. M. \& Shoemaker, K. (1971). Communication of Innovation: A Cross-Cultural approach ( $2^{\text {nd }}$ ed.). London: Collar Macmillan Publisher.

Rondinelli, D. A. \& Ruddle, K. (1976). Urban Function in rural Development. Washington DC.

RUPP (2003). Harnessing ICT's for local development: The Case of rural urban partnership program in Nepal (Nep/01/020) (29-31 October 2003, Shanghai Chaina.

Sharma, M. (1998). Pitamber,Market and small towns in the HinduKush Himalayas, Alternative Modes of Urbanization Issue in Mountain Development.

Von Thunen, J. H. (1826). Der Isolierate Staat in Beziehung auf Landwirtschaft und Nationalokonomie. Hamburg: Friedrich Perthes. English translation by Peter Hall, ed.Von Thunen's Isolated State in 1966. Oxford: Pergamon Press.

VDC Profile (2014). A Profile of Bima Village Development Committee. Author.

VDC Profile (2014). A Profile of Darbang Village Development Committee. Author. 